\title{
Changes in the Network of Estonian General Education Schools
}

\author{
Veronika Varik
}

\begin{abstract}
After the restoration of independence, the fate of small schools became a topical issue in Estonia. The structure of the school network is an important factor in making education accessible, and any alteration can lead to a direct impact on people's daily lives whether it be in the form increased school travel time when a local school is closed down, diminished access to education, loss of a regional centre and many jobs, or, more positively, a new-found sense of regional perspective when a new school is opened. This paper aims to provide an analytical overview of the changes in the Estonian general education network that were driven by four main factors: declining birth rate, population relocation (peri-urbanisation), educational policy, and economic development. The methods used in this theoretical study are textual analysis and source criticism. Changes in the school network are analysed by drawing on national statistics, legislative acts, and published and unpublished materials. Given that the national governments from 1990-2004 had no uniform plans for developing the school network, two countervailing tendencies could be observed: preserving the status quo and unmanaged development. The first tendency strove to maintain the existing population and spatial structures whereas the second was expressed in the actions of the schools themselves, leading to an increasing gap between strong and weak schools and school administrators. Preserving the status quo was not favoured by the per-student funding model. However, a drastic consequence of unmanaged development was (due to the demographic situation and opportunities for optimisation) that the problems with schools gradually resolved themselves on a case-by-case basis (i.e., students and teachers first trickled and then poured out from certain regions). During this period, regional differences between schools became more pronounced and economic stratification led to educational stratification.
\end{abstract}

Keywords: general education schools, school network, demographic trends, educational policy

\section{Introduction}

The development of the school network in newly-independent Estonia was significantly influenced by Soviet education policy trends and principles, which envisaged a transition to compulsory secondary education (grades 1-11). In particular, this comprised the reorganisation of the school network in rural areas: the concentration of agricultural production on large-scale state farms had led to the growth of new settlements. Thus, the collapse of the Soviet system meant that several regions saw a decline in student numbers: many schools were either reorganized or closed and students were redirected to basic and secondary schools in rural and urban centres. 
In addition to economic and demographic factors and education policy trends, the development of the school network was also affected by attitudes of the general population. In the transitional society of post-Soviet Estonia, parents began to re-assess the significance of elementary education: it truly became the first step in the future careers of their children. Small rural schools became less credible as guarantors of good education in the eyes of society. Accordingly, the number of students in small schools dropped.

After Estonia regained independence, its education policy officials were faced with a complex dilemma - management with limited financial and material resources or maintenance of the role of schools as engines of regional development. Steadily decreasing birth rates and intensified relocation to areas with better opportunities for living, working, or raising children meant that the small rural schools that had survived the industrialisation and urbanisation craze of the 1960s-1970s remained very much under threat in the 1990s.

Neighboring countries (Latvia and Finland) ${ }^{1}$ faced similar demographic trends in the 1990s and also needed to reorganize their school networks. By restructuring its school network, Estonia tried to align the study places and conditions with these demographic changes, keeping in mind actual financial capacity.

This paper aims to provide an analytical overview of the changes in the Estonian general education network that were driven by four main factors: declining birth rate, population relocation (urbanisation), educational policy, and economic development. The methods used in this theoretical study are textual analysis and source criticism. Changes in the school network were analysed by drawing on national statistics, legislative acts, and published and unpublished materials.

\section{Demographic trends and the school network}

Demographic trends have had a profound effect on the school network. Since the 1990s, Estonia has undergone a population decline. From 1989 to 2000, the population of Estonia decreased by approximately 200000 (1 565662 in 1989 to 1370052 in 2000). This was due to natural population decrease especially in the first half of the 1990s - and emigration. The latter was primarily prompted by the collapse of the Soviet occupation, after which a large number of military personnel and employees of Soviet All-Union enterprises left the country. The birth rate dropped from 24000 in 1989 to 12000 in 1998. Only in 1999 was the number of births in Estonia slightly higher than the previous

\footnotetext{
Reviews of National Policies for Education, Latvia, OECD, 2001, pp. 65-66. Available: http://dx.doi. org/10.1787/9789264192478-en (accessed 14 July 2017); J. Vasama, 'Koolivõrk, Soome kogemus' [School network, Finnish experience], manuscript, 2005, Tallinna Ülikooli Eesti pedagoogika arhiivmuuseum [Tallinn University Estonian Pedagogical Archives and Museum], K42490-7.
} 
year, reversing the trend of the previous 11 years. Growth continued from 2000 to $2020 .^{2}$

The number of students in general education schools began to decrease in 1999. From 1999 to 2004, the number of students in general education schools fell by approximately 15\% (31 890 students). Up to 1998, 22 000-23 000 students began first grade annually; from 2001 to 2004 this number remained stable at 13000 . Although the majority of children studied in larger cities, the share of day students in rural schools increased by approximately $4 \%$ (from $23.8 \%$ in 1990 to $27.6 \%$ in 2004$){ }^{3}$

The demographic situation differed from region to region due to a number factors, not the least of which was geography. The collapse of the Soviet Union and its collective farm system and changes in the structure of the economy and its development concentrated the population in cities and peri-urban settlements. Demographic changes were less negative in larger cities and their immediate surroundings. In certain regions, the process of urbanization resulted in a shortage of kindergarten spaces and a lack of pupils in schools. Problems were most severe in small towns and peripheral regions: the demographic situation in rural municipalities was greatly influenced by their position on the center-periphery axis, i.e., their geographical distance from larger cities. Due to the decreasing numbers of students, many municipalities had to restructure their school networks. In addition to demographic factors and migration, the structure of the school network was determined by education policy trends and decisions at the national and municipal levels.

\section{Education policy and the school network}

The network of Estonian general education schools was decentralized in 1990. With the Local Government Organisation Act (1993), the responsibility for educational institutions was passed from the state to municipal governments, ${ }^{4}$

2 M. Servinski, Ü. Valgma, B. Hänilane, M.-L. Otsing, 'Rahvastiku paiknemine ja rahvaarv' [Population and distribution of population], in T. Rosenberg (ed.), Pilte rahvaloendusest [Census snapshots], Tallinn, 2013, pp. 9-22. Available: http://www.digar.ee/arhiiv/et/raamatud/55227 (accessed 3 July 2017); 'Noppeid ajaloost, Sündimus' [Scrolls from history, Birth rate], Statistikablogi, Statistikaameti ajaveeb [web blog], 13 July 2016. Available: https://statistikaamet. wordpress.com/tag/sundimus/ (accessed 3 July 2017).

3 B. Aaviksoo, 'Väikekoolide sulgemine haridusõiguse piirajana, Piirangu kooskõla Põhiseadusega, Analüüs' [Closure of small schools as limiting educational rights. Convergence of the limiting with the Constitution. Analysis], manuscript, 2001, Archives of the Office of the Legal Chancellor of the Republic of Estonia, p. 15; Ülevaade üldharidusest 2001-2005 [Overview of general education 2001-2005], Tartu, Haridus- ja Teadusministeerium, 2005, p. 14. Available: http://dspace.ut.ee/bitstream/handle/10062/40907/Uldharidus_2001_2005.pdf? sequence $=1$ \&isAllowed $=y$ (accessed 11 July 2017); 'Statistikaamet, Statistika andmebaas, Üldharidus' [Statistical Office, Database of Statistics, General Education]. Available: https:// www.stat.ee/andmebaas (accessed 11 July 2017).

4 'Kohaliku omavalitsuse korralduse seadus (1993)' [Local Government Organisation Act (1993)], Riigi Teataja [State Gazette], vol. I-37, no. 558, 1993. Available: https://www.riigiteataja. ee/akt/28501 (accessed 9 June 2017). 
including responsibility for facilities and school staff. Most schools for special educational needs children continued to be administered by the state (34 out of 50 in 1994). ${ }^{5}$ Although the number of general education schools steadily grew in the second half of the 1980s, there was a surge from 1990 to 1995: the number of schools (mainly primary and basic schools) increased from 641 to 742 . On the one hand, the disappearance of large collective farms in rural areas required smaller and geographically closer schools. Emerging small farms and local businesses brought places of work nearer to home. On the other hand, the dramatic increase in the number of schools has been linked to a particular mentality of the 1990s: the newly-independent state wanted to compensate for Soviet-era closures of small schools by building new ones, all the while failing to foresee the imminent decline of rural life and the sharp decrease in births. The number of general education schools continued to grow until 1995 and then began to dwindle. ${ }^{6}$ In addition to the falling birth rate, another decisive factor in the closing of small schools was the education policy.

In 1993, Estonia adopted a per-student based funding model for general education schools. ${ }^{7}$ According to this model, the amount of resources allocated to a municipality for teacher salaries and training fees, textbooks and investments was linked to the total number of students who attended school in that municipality, regardless of the number or level of schools. ${ }^{8}$ One of the aims in adopting this model was increased control of the school network because lax government control in the early 1990s resulted in relatively unchecked development, and the number of small schools soared. The per-student funding model gave larger schools a competitive advantage: the annual budgets of small schools with low student numbers could not meet their actual needs because they had utilities and administrative expenses similar to those of larger schools.

The market economy infiltrated education and pushed schools to compete for pupils. One important regulatory mechanism facilitating this was a provision in the Basic Schools and Upper Secondary Schools Act (1993), allowing parents

5 V. Neare, 'Eripedagoogika probleemid haridusametniku pilgu läbi' [Problems of special education through the eyes of an educational officer], in Eesti puuetega laste koolid [Schools for children with disabilities in Estonia], Tallinn, Eesti Eripedagoogide Liit, 1994, p. 9.

6 B. Aaviksoo, 'Väikekoolide sulgemine haridusõiguse piirajana, Piirangu kooskõla Põhiseadusega, Analüüs' [Closure of small schools as limiting educational rights. Convergence of the limiting with the Constitution. Analysis], manuscript, 2001, Archives of the Office of the Legal Chancellor of the Republic of Estonia, p. 15; V. Varik, 'Hariduspoliitika ja üldhariduskorraldus Eestis aastatel 1940-1991' [Educational policy and organisation of general education in Estonia during 1940-1991], PhD diss., University of Tallinn, 2006, p. 188; 'Statistikaamet, Statistika andmebaas, Üldharidus' [Statistical Office, Database of Statistics, General education]. Available: https://www.stat.ee/andmebaas (accessed 9 January 2017).

7 The number of students attending schools in a given municipality is used to calculate the amount of state subsidies allocated to that particular municipality. Funding is "bound" to students and "moves along" with them in case they relocate or switch schools. The subsidy is used to cover teacher salaries, social taxes, training, and textbooks.

8 'Põhikooli- ja gümnaasiumiseadus (1993)' [Basic Schools and Upper Secondary Schools Act (1993)], Riigi Teataja [State Gazette], vol. I-63, no. 892, 1993. Available: https://www.riigiteataja. ee/akt/28542 (accessed 9 June 2017). 
to choose the school for their child. ${ }^{9}$ Schools had general catchment areas within municipalities, but when students switched to schools in a municipality they did not live in, a certain amount of funding went to that other municipality.

According to 2004-2005 Ministry of Education and Research study, 14\% (3628) of primary level pupils did not attended school in their municipality although $98.4 \%$ had schools available in their municipalities. For grades 4 to 6 , the percentage of "migratory pupils" was 21\% (5375), and for grades 7 to 9 the number rose to $30 \%$ (7656). Of these pupils, $95.4 \%$ and $88.1 \%$ respectively had schools available in their municipalities. Frequent voluntary "migration" in compulsory education (grades 1-9) raised questions about the underlying causes. The study showed that parents tended to prefer schools that offered all three stages of study (grades 1-12, including gymnasiums). Schools with grades 1 to 12 are historic in Estonia.

However, there were some inconsistencies in parent behavior. On the one hand, they wanted their children to learn in smaller classes, but on the other hand, they preferred to send their children to large gymnasiums ${ }^{10}$ early on to ensure later access to good secondary education (yet, the lower grades in these gymnasiums were most definitely overcrowded). ${ }^{11}$ Education was becoming a means of defining one's social position. Parent choices were influenced by the prestige and imagined quality of the school.

The choice of school was also determined by signals in the education market, even more so after the introduction of state examinations for secondary school graduates in 1997 to ensure the quality of general education. The results of these exams enabled the state to assess how well students had done in their studies. Furthermore, they could also be used by universities for determining student admission. However, this mechanism quickly became an important public measure for assessing the work of schools and teachers, thus boosting competition between schools. It became trendy to rank schools based on state examination results. Those with results averaging close to $100 \%$ were considered elite schools. The introduction of secondary school state exams strengthened

\footnotetext{
9 Põhikooli- ja gümnaasiumiseadus (1993)' [Basic Schools and Upper Secondary Schools Act (1993)], Riigi Teataja [State Gazette], vol. I-63, no. 892, 1993. Available: https://www.riigiteataja. ee/akt/28542 (accessed 9 June 2017); 'Põhikooli- ja gümnaasiumiseaduse muutmise seadus (1997)' [Act amending and supplementing the Basic Schools and Upper Secondary Schools Act (1997)], Riigi Teataja [State Gazette], vol. I-24, no. 365, 1997. Available: https://www.riigiteataja. ee/akt/31593 (accessed 9 June 2017).

${ }^{10}$ Especially in the "elite" schools - gymnasiums with specialized programs (foreign languages) inherited from the Soviet era with excellent graduation results and shining reputations. Such schools could be found mostly in bigger cities (Tallinn, Tartu) and having children study in such schools increased expenses significantly.

${ }^{11}$ Üldhariduskoolide võrgu korraldamine, Lühikokkuvõte [Organisation of general education school network. Brief summary], Tartu, Poliitikauuringute Keskus Praxis, 2005, pp. 6, 13. Available: http://www.praxis.ee/wp-content/uploads/2014/03/2005-Uldhariduskoolide-vorgukorraldamine-luhikokkuvote.pdf (accessed 12 July 2017).
} 
the position of elite schools in society, and the introduction of entrance exams for first-graders extended educational selectivity to the pre-school level. ${ }^{12}$

Although there were efforts by various parties to reach a state-level agreement on the fundamentals of education, no consensus was found, thus complicating the formation of an optimal and comprehensive school network that would promote national educational priorities and regional development.

Since the state did not interfere with schools' struggles for survival, each municipality and county managed its own school network and education. During transition, the guiding principle in development of the Estonian school network was self-regulation. Schools able to cope with the new circumstances proved to be most sustainable. In most cases, these were schools administered by stronger and wealthier municipalities. Economically weaker schools, mostly in peripheral regions, experienced great difficulty, and lack of support from parents and local activists often forced them to close. Another important process was the various attempts to preserve the existing situation, but this was hindered by the per-student funding model. Consequently, the overall trend in the development of the general education network was a decrease in the number of schools.

At the beginning of the academic year 1995/96, there were 742 schools in Estonia. By the end of 2004/2005, 598 schools remained. Of the 144 schools that had closed, 105 were primary schools. ${ }^{13}$ By the end of 2004/2005, ten out of Estonia's fifteen counties had closed at least half of their primary schools. It is especially noteworthy that approximately $40 \%$ of the new schools founded after restoration of independence had closed by $2005 .{ }^{14}$

After 1998/1999, the number of schools began to drop significantly (15-20 each year) with the greatest drop in 2001/2002 when 30 schools closed. Upper secondary schools were least affected - only four closed from 1995 to 2004. The number of basic schools kept growing until 1996/97 (270 schools), but then dropped to 225 by $2004 .^{15}$

${ }^{12}$ K. Loogma, 'Haridusmuutused Eestis: haridussotsioloogiline lähenemine' [Education changes in Estonia: educational sociological approach], in R. Tammist, H. Rumm (eds.), Eesti poliitika eile, täna, homme: reforme seitsmest valdkonnast [Estonia's policy yesterday, today, tomorrow: reform of the seven areas], Tartu, Johannes Mihkelsoni Keskus, 2005, pp. 109, 110; L. Jõgi, T. Jääger, L. Roodla, 'Eesti haridussüsteem ja hariduspoliitika aastatel 1990-2000' [Estonian education system and education policy 1990-2000], in R. Pae (ed.), Eesti ja Soome haridus ning muutused EL-i hariduspoliitikas 1990-2000 [Estonian and Finnish education and changes in EU education policy 1990-2000], Tallinn, Tallinna Ülikooli kirjastus, 2008, p. 124.

13 'Statistikaamet, Statistika andmebaas, Üldharidus' [Statistical Office, Database of Statistics, General education]. Available: https://www.stat.ee/andmebaas (accessed 11 July 2017).

${ }^{14}$ P. Kreitzberg, 'Hariduslike võimaluste võrdsus ja koolivõrk' [Equality of educational opportunities and the school network], manuscript, 2005, Tallinn University Estonian Pedagogical Archives and Museum, K42490-8.

15 Ülevaade üldharidusest 2001-2005 [Overview of general education 2001-2005], Tartu, Haridus- ja Teadusministeerium, 2005, pp. 25-26. Available: http://dspace.ut.ee/bitstream/ handle/10062/40907/Uldharidus_2001_2005.pdf?sequence=1\&isAllowed=y (accessed 11 July 2017). 
The number of schools also decreased due to mergers. A merger was not equivalent to closure for it did not reduce education opportunities in the region. Schools were merged in two ways. First, the teaching/learning process was concentrated into existing school buildings after merger. This option was more common in cities. Or, two or more schools shared administration, but students continued to study in their former school buildings. This approach was more likely to be applied in rural areas where physical distance between the merged schools could exceed ten kilometers. It is noteworthy that school mergers began to be implemented only in 1999. From 1999 to 2003, 20 schools were merged, $65 \%$ of which were in rural areas: in 13 cases, pupils continued to attend classes in their former school building. As with closures, the highest number of mergers took place in 2001/02. ${ }^{16}$

A school was closed usually because of a lack of pupils in the catchment area. In addition, an allegedly lower quality of education in small schools was also cited. However, the decisive factor was most often lack of financial resources in the municipality. ${ }^{17}$ Although 15 new schools opened from 1994-2003, this did not change the overall trend of a shrinking school network. ${ }^{18}$

Since each school creates learning opportunities for pupils of a particular age group, each closed school meant fewer opportunities for pupils in a particular school level in the region. The Ministry of Education identified social justice as one of its priorities in its 1998 education strategy, ${ }^{19}$ but such measures were not ultimately implemented at the national level.

The fundamental question that emerged from discussions on closing of small schools concerned the burden that it placed on children and their parents. There were no legally specified limits on school travel time in Estonia. Finnish School Law (1999), for example, contains an important criterion that effectively determines the density of the school network: a full-time pupil (13 years or younger) must not spend more than 2.5 hours per day travelling to and from school (including wait times). For children over 13 and children with special needs, the maximum is 3 hours. ${ }^{20}$ In Estonia, the Basic Schools and Upper

${ }^{16}$ Ülevaade üldharidusest 2001-2005 [Overview of general education 2001-2005], Tartu, Haridus- ja Teadusministeerium, 2005, pp. 25-26. Available: http://dspace.ut.ee/bitstream/ handle/10062/40907/Uldharidus_2001_2005.pdf?sequence=1\&isAllowed=y (accessed 11 July 2017).

${ }^{17}$ B. Aaviksoo, 'Väikekoolide sulgemine haridusõiguse piirajana, Piirangu kooskõla Põhiseadusega, Analüüs' [Closure of small schools as limiting educational rights. Convergence of the limiting with the Constitution. Analysis], manuscript, 2001, Archives of the Office of the Legal Chancellor of the Republic of Estonia, p. 16.

18 Ülevaade üldharidusest 2001-2005 [Overview of general education 2001-2005], Tartu, Haridus- ja Teadusministeerium, 2005, pp. 25-26. Available: http://dspace.ut.ee/bitstream/ handle/10062/40907/Uldharidus_2001_2005.pdf?sequence=1\&isAllowed=y (accessed 11 July 2017).

${ }^{19}$ Eesti haridusstrateegia (eelnõu) [Estonian educational strategy (draft)], Tallinn, Haridusministeerium, 1998, Article 151.1, p. 32.

${ }^{20}$ Valtioneuvoston oikeuskanslerin kertomus [Report of the Chancellor of Justice], Helsinki, 2001, p. 157. Available: https://www.okv.fi/media/uploads/kertomukset/arkisto_1997-2011/okv2000. pdf (accessed 13 July 2017). 
Secondary Schools Act Amendment Act of 1999 denotes the minimum number of students required for opening a new school - 30 appropriately-aged children living permanently in the catchment area for a primary school, 60 for a sixyear elementary school, and 90 children for a basic school (grades 1-9). For secondary school (grades 10-12), the minimum number of students was 60 . If a municipality decided to open a school with a smaller number of students than specified, it would have had to cover part of the staff salaries from its own budget. ${ }^{21}$ But, municipalities already saw 90 students as the critical threshold for basic schools: fewer would have resulted in significant administrative and other difficulties.

Small rural school issues were also mentioned in the 2001 OECD Review, which presented a joint set of proposals for the future development of the Baltic states. One recommendation was to reduce discrepancy in the quality and availability of education between the urban and rural areas. OECD experts pointed out that school closures were too often motivated solely by considerations of economic efficiency, failing to recognize the wider implications. ${ }^{22}$ In his October 2001 analysis, the Estonian Chancellor of Justice of Estonia pointed out that the Estonian school network was being run without any central planning or improvements. His analysis suggested that this could amount to a violation of the Constitution: "Everyone has the right to education. ... In order to make education accessible, the national government and local authorities maintain a requisite number of educational institutions."23

The Chancellor's analysis also emphasized that although state supervision had focused on curricula, the Ministry of Education had to also ensure that key educational policies and decisions were consistent with the Constitution and laws. This concurred with the Finnish Chancellor of Justice who stated that economic arguments that do not directly result from the Constitution are not sufficient to justify any restrictions on the education law. Any decision to close a school should be accompanied by specific calculations demonstrating that even with all possible measures (improved administrative efficiency, compound classes) in place, the municipality would not be able provide its other social services without closing the school. ${ }^{24}$

21 'Põhikooli- ja gümnaasiumiseaduse muutmise ja täiendamise seadus (1999)' [Act amending and supplementing the Basic Schools and Upper Secondary Schools Act (1999)], Riigi Teataja [State Gazette], vol. I-24, no. 358, 1999. Available: https://www.riigiteataja.ee/akt/77246 (accessed 9 June 2017).

${ }^{22}$ Riiklike hariduspoliitikate ülevaated, Eesti [Reviews of national policies for education, Estonia], OECD, 2001, pp. 17, 24. Available: http://digar.nlib.ee/show/nlib-digar:9588 (accessed13 July 2017).

${ }^{23}$ B. Aaviksoo, 'Väikekoolide sulgemine haridusõiguse piirajana, Piirangu kooskõla Põhiseadusega, Analüüs' [Closure of small schools as limiting educational rights. Convergence of the limiting with the Constitution. Analysis], manuscript, 2001, Archives of the Office of the Legal Chancellor of the Republic of Estonia], p. 20.

${ }^{24}$ B. Aaviksoo, 'Väikekoolide sulgemine haridusõiguse piirajana, Piirangu kooskõla Põhiseadusega, Analüüs' [Closure of small schools as limiting educational rights. Convergence of the limiting 
In 2003, counties began to create county-level school network development plans by analysing regional needs and opportunities to create the best possible learning environment for youth. However, they did not follow uniform methodological guidelines, so approaches and thoroughness of projections varied considerably from county to county. Additionally, school sustainability differed in the plans: some preferred to highlight the process (strategic courses of action), but others set specific target values to be pursued in education administration. Resulting development plans were not easily compared because there was little systematisation or consensus on school sustainability indicators on the national level. ${ }^{25}$

The situation was critical, and the need for change in the funding model of general education was felt by all institutions, so the system was modified in 2000. Municipalities were divided into groups based on numbers of pupils (coefficients from 0.89 for cities with more than 5000 pupils to 1.5 for rural municipalities with fewer than 120). The implementation of coefficients allowed smaller municipalities to receive slightly higher allocations for educationrelated expenses. In 2005-2006, a radical reform for general education funding was in preparation but failed to garner sufficient political support. ${ }^{26}$ Since 2008 , Estonia has used a funding model that is still based on the number of pupils, but it also takes into account the actual upkeep costs of schools. The new model promotes survival of smaller primary schools, which is important for ensuring proper access to education.

The effects of the administrative and curricular changes were reflected in the results of the 2004 complex study of Estonian schools. When asked to evaluate their child's school on a 6-point scale (6 - excellent), $76 \%$ of parents (71\% in rural schools) rated it between 4 and $6 ; 28 \%$ of rural parents would change schools if possible. ${ }^{27}$ The study included $12 \%$ of Estonia schools. It appears that parents were quite satisfied with schools but lacked the opportunity to switch to another if they wished.

with the Constitution. Analysis], manuscript, 2001, Archives of the Office of the Legal Chancellor of the Republic of Estonia], pp. 16-22.

${ }^{25}$ Üldhariduskoolide võrgu korraldamine, Lühikokkuvõte [Organisation of general education school network. Brief summary], Tartu, Poliitikauuringute Keskus Praxis, 2005, pp. 6, 7. Available: http://www.praxis.ee/wp-content/uploads/2014/03/2005-Uldhariduskoolide-vorgukorraldamine-luhikokkuvote.pdf (accessed 12 July 2017).

${ }^{26}$ J. Reiljan, E. Reiljan, 'Eesti üldhariduse rahastamise olukord ja probleemid' [Situation and problems of financing general education in Estonia], 2005, pp. 126, 136. Available: http:// www.academia.edu/18212423/Eesti_\%C3\%BCldhariduse_rahastamise_olukord_ja_probleemid (accessed 15 July 2017).

${ }^{27}$ L. Pallas, Kooli ópikeskkond ja ópilaste toimetulek. Ankeet lapsevanemale. Tabelid [School as learning environment and students' coping abilities. Parent survey. Tables.], Tallinn, Tallinna Ülikool, 2008; E.-S. Sarv, Õpetaja ja kool ópilase arengu toetajana. Õpetaja enesest ja koolist [Teacher and school as supporters of student development. Teacher on her/himself and on school], Tallinn, Tallinna Ülikooli Kirjastus, 2008. pp. 92-93. 


\section{Economic development and the school network}

Following transition to self-management in January 1990, Estonia began dismantling Soviet-era economic structures (All-Union subsidiaries were liquidated or divided into smaller business units and large-scale farming was reorganised) and turned towards a Western-oriented economic system. The first years of restructuring were particularly complex, and in the early 1990s, the economy slumped. Economic transformations also affected education. During the Soviet era, insufficient state funding was offset by allocations from companies and collective farms. In a market economy, businesses were often under much pressure and schools did not receive any additional support from them. Many municipalities were not able, at least initially, to fill the resulting financial gap.

While transitioning from one socio-economic system to another, Estonia faced a difficult dilemma. On the one hand, it had to spend relatively more on education than highly-developed countries in order to catch up with them. On the other hand, many other crucial fields besides education were in similar need of development. Resulting expenditure on general education was unstable, ranging from 3.5 to $4 \%$ of the gross domestic product (GDP). This volatility notwithstanding, the expenditure on general education grew somewhat faster than the GDP from 1996-2004. Estonia's expenditure on education relative to its GDP slightly exceeded the European Union average, but its nominal level of funding was one of the lowest in the European Union. Only in 1999 could Estonia allocate more money to teaching activities and investment than to upkeep of school buildings. However, expenditure on general education declined again from 1999-2001. The level of funding stabilized in 2002 and 2003, and in 2004, a significant increase in the expenditure on education relative to GDP was achieved (reaching the level of 1999). ${ }^{28}$

It would not be fair to say that Estonia under-appreciated the social value of spending on education. In 2001, 5.5\% of GDP was allocated to education, which was slightly more than the average in the European Union $15.1 \%$ of GDP). Low population density and the relative abundance of small schools and small classes caused Estonia to deal with relatively higher costs than other, more densely populated countries. In other words, an average was simply not good enough to catch the frontrunners. The level of funds allocated to education did not depend merely on the perceived social value of education, which was historically high in Estonia; it depended more on the level of economic development that determined the actual financial capacity of the country.

\footnotetext{
${ }^{28}$ J. Reiljan, E. Reiljan, 'Eesti üldhariduse rahastamise olukord ja probleemid' [Situation and problems of financing of general education in Estonia], 2005, pp. 127, 129-130, 132, 134. Available: http://www.academia.edu/18212423/Eesti_\%C3\%BCldhariduse_rahastamise_ olukord_ja_probleemid (accessed 15 July 2017).
} 
Issues of general education funding were debated not only in Estonia but also all over the world ${ }^{29}$ as equal access to education is one of the main contributors to social mobility and a key factor in the growth of human capital that determines how countries develop. Various accounts of education funding often highlighted two aspects - equality and efficiency. The former emphasized the importance of securing equal opportunities, while the latter stressed the efficient use of resources. ${ }^{30}$

In order to offset the shortcomings of the national system, private individuals and associations (in cooperation with local governments and with considerable help from foreign aid) established new educational institutions private schools, including schools for children with special educational needs. The first private schools in Estonia were founded in 1990. Their numbers grew from 21 in 1993/94 to 32 by the end of 2004/2005. ${ }^{31}$ The earliest private schools were largely driven by a desire to introduce new ideas (e.g., Waldorf pedagogy) into education and society. The emergence of private schools can be regarded as a sign of social yearning for a substantive change in education.

\section{Conclusion}

The network of Estonian general education schools was decentralized in 1990 after which the state handed its decision-making powers and responsibilities for schools over to municipal governments. Decentralisation and liberalisation resulted in a sharp increase in the number of general education schools during the first decade of independence. However, the same decade also saw a rapidly declining birth rate, which led to a marked decrease in the number of pupils, which has pressured municipalities to close schools or school districts since the end of the 1990s. In addition to demographic trends (including urbanisation), restructuring of the school network was also determined by educational policy decisions and underfunding of general education. Comprehensive solutions to problems in the school network were impeded by municipalities that closed schools. The Constitution forbade the state from interfering with these decisions.

The number of schools continued to decrease in the 2000s. The percentage of basic schools (grades 1-9) remained effectively the same over the years,

${ }^{29}$ D. Aaronson, 'The Effect of School Finance Reform on Population Heterogeneity', National Tax Journal, no. 52, 1999, pp. 5-29; R. Berne, M. Moser, L. Stiefel, 'Social Policy: School Finance,' Journal of Management History, vol. 5, no. 3, 1999, pp. 165-179; T. Nechyba, 'Public School Finance and Urban School Policy: General versus Partial Equilibrium Analysis', in BrookingsWharton Papers on Urban Affairs, Washington, Brookings Institution Press, 2003, pp. 176-180.

${ }^{30}$ R. Berne, M. Moser, L. Stiefel, 'Social Policy: School Finance,' Journal of Management History, vol. 5, no. 3, 1999, pp. 165-179.

${ }^{31}$ Erakoolid Eestis [Private schools in Estonia], Tallinn, Kultuuri- ja Haridusministeerium, 1994, p. 11; 'Statistikaamet, Statistika andmebaas, Õpe üldhariduskoolides: erakoolid' [Statistics Estonia. Database of statistics. Training in general education schools: private schools]. Available: https://www.stat.ee/andmebaas (accessed 12 September 2017). 
while the percentage of upper secondary schools (grades 1-12; 224 in 1990, 236 in 2004) increased at the expense of primary schools (grades 1-6).

Given the importance of schools in bringing about balanced regional development, Estonia should continue to acknowledge that its low population density and small schools and small classes will result in a somewhat costlier education system. Other challenges include adapting to demographic trends and synchronization of the quality of educational services across the regions. 